\title{
Biosorption of Metallic Elements onto Fen Peat
}

\author{
Janis Krumins ${ }^{1}$, Artis Robalds ${ }^{2},{ }^{1-2}$ University of Latvia
}

\begin{abstract}
Industrial development and anthropogenic activity have a huge impact on the environment, forcing society to find new and cost-effective environment treatment technologies. One of the most effective and environmentally friendly methods is the use of biosorbents, for which peat is one of the most cost-effective materials. The adsorption capabilities of peat sediments are well known; however, mainly raised bog peat is used for environmental treatment, and thus the abilities of fen peat are underestimated. The aim of this research was to assess the fen peat suitability as an adsorbent for metallic elements. In this study we have determined the sorption characteristics of $\mathrm{Ca}, \mathrm{Mg}$, $\mathrm{K}, \mathrm{Na}, \mathrm{Cu}$ and $\mathrm{Pb}$ and results show that fen peat deposits have a huge variability as a biosorbent due to their variable botanical composition and complex properties, for instance, under equal conditions, wood-sedge peat can have higher lead adsorption capacity than wood peat. However, due to its natural content of metallic elements, the sorption capacity overall is lower than it is for raised bog peat, although the high $\mathrm{pH}$ reaction encourage a high mobility metals.
\end{abstract}

Keywords - Biosorption, fen peat, metallic elements.

\section{INTRODUCTION}

In Latvia peat is used in much smaller amounts than it would be economically justified, even without compromising the natural values, because a significant part of Latvian mires are located in various nature reserves, where peat harvesting is prohibited. The main scope of companies is raised bog raw peat harvesting for the local market and export. Thus the main challenge is what to do with fen peat after raised bog peat layer removal in bogs and with peat in fens - is there any perspective for usage of this material. Even though the most popular is to use peat as a raw material in such areas as heating or power generation (where fen peat usually is not the best option), uses of it goes far beyond this point. In our study, fen peat is viewed as a valuable natural resource and its possibilities as base material for biosorption. In general, "biosorption may be simply defined as the removal of substances from solution by biological material" [1].

The formation of peat takes place in anaerobic conditions and is followed by the accumulation of organic carbon. Thus the mire formation is a significant part of the biogeochemical cycle of carbon and other elements, which, at the same time, depends on the variability of the environmental conditions. The high content of acidic functional groups in peat provides the ability to bind major and trace elements included in the remains of living organisms and to accumulate them as a specific chemical compound or to bind them in complex substances. The main sources of the elements in peat mass are peat forming microorganisms, ground waters and precipitation (Table I). While the ability of peat to accumulate chemical elements depends on: 1) the ion capacity to bind with functional groups (in particular, with carboxyl- and phenol hydroxyl groups), 2) $\mathrm{pH}$ reaction, 3) presence of the low molecular weight compounds (carboxylic acids, polyphenols) and other dissociating compounds, for instance, sulphate or hydrogen carbonate ions.

The chemical composition of peat changes according to its placement in the vertical and horizontal level, water table fluctuations and peat forming plant composition and decomposition characteristics. The increase of the anthropogenic impact also can cause various additional conditions. The drainage and use of peat in agriculture and forestry can significantly affect element accumulation.

TABLE I

Conceptual Model of Peat Chemical Composition

\begin{tabular}{|c|c|c|c|c|}
\hline \multirow{19}{*}{ ت } & \multicolumn{4}{|c|}{ Water } \\
\hline & \multirow{18}{*}{ 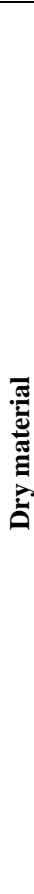 } & \multirow{4}{*}{ 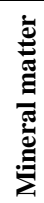 } & \multirow{3}{*}{ Metals } & Heavy metals \\
\hline & & & & $\mathrm{Fe}, \mathrm{Al}$ \\
\hline & & & & $\mathrm{Na}, \mathrm{K}, \mathrm{P}, \mathrm{Mg}, \mathrm{Ca}$ \\
\hline & & & \multicolumn{2}{|l|}{ Anions and silicon } \\
\hline & & \multirow{14}{*}{ 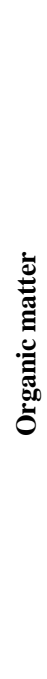 } & \multirow{5}{*}{ Aminoacids } & Sugars \\
\hline & & & & + charged \\
\hline & & & & - charged \\
\hline & & & & Uncharged \\
\hline & & & & Nonpolar \\
\hline & & & \multirow{3}{*}{ Carbohydrates } & Hexoses \\
\hline & & & & Pentoses \\
\hline & & & & Deoxysugars \\
\hline & & & Lignin & \\
\hline & & & Uronic acid & \\
\hline & & & \multirow{3}{*}{ Bitumen } & Fats \\
\hline & & & & Wax \\
\hline & & & & Lipids \\
\hline & & & $\mathrm{C}, \mathrm{H}, \mathrm{N}, \mathrm{S}, \mathrm{O}$ & \\
\hline
\end{tabular}

Lots of studies show an increase of the amount of several chemical elements in the peat mass during the last hundred years on the account of anthropogenic pollution. Due to the ability to bind pollutants (which are mainly supplied via precipitation and water flow), peat and mire plants can successfully be used as pollution indicators. In many countries the sorption abilities of moss and peat are used for environmental monitoring, for studying and predicting expected changes in pollution levels. The element accumulation characteristics because of the nature of the environmental pollution and peat composition can be regional.

Accumulation of chemical elements in peat profiles serve as valuable archives of natural and human induced change. The concentration of major elements in peat is influenced by the 
general environmental settings in the area. At the same time, the sorption capacity of trace elements is affected by peat properties. It depends on oxygen containing functional groups and it is growing with an increasing degree of decomposition. In addition, fen peat seems to be largely saturated in respect to metal ions, while for raised bog peat - it is the opposite. In the latter case, metal sorption takes place due to competition with $\mathrm{Ca}^{2+}$ and $\mathrm{Mg}^{2+}$ which are general major elements common to fen peat. The final pattern of major and trace element accumulation depends on the balance between natural and human inducted processes, but at low pollution levels, natural element accumulation prevails.

The application of FT-IR spectroscopy on peat provides data about the nature of oxygen and hydrogen containing functional groups, their structural array, relations, etc. [2-3]. However, it should be remembered that this method only indicates the presence of one or another functional group. Certain functional groups absorb IR light at characteristic frequencies (Table II). Thus it is possible to identify chemical structures common to a singular peat sample [4]. The greater part of absorption zones for functional groups common to peat are located in the so-called middle range of the IR spectra at a wavelength interval from $400 \mathrm{~cm}^{-1}$ to $4000 \mathrm{~cm}^{-1}$. The general absorption range can be separated in three main areas: 1) the "Fingerprint region" in a wavelength interval from $400 \mathrm{~cm}^{-1}$ till $1500 \mathrm{~cm}^{-1}$; 2) absorption of double bounded groups in a range from $1500 \mathrm{~cm}^{-1}$ to $2500 \mathrm{~cm}^{-1}$ and 3) "R-H region" in a range from $2500 \mathrm{~cm}^{-1}-4000 \mathrm{~cm}^{-1}$ [2].

TABLE II

COMMON FUnCTIONAL GROUPS ON FT-IR SPECTRA OF PEAT

\begin{tabular}{|l|l|}
\hline Wavenumber, $\mathbf{c m}^{-1}$ & Assignment \\
\hline $750-880$ & $\begin{array}{l}\text { Hydrogen-bonded } \mathrm{OH} \text { stretching of carboxylic } \\
\text { groups. }\end{array}$ \\
\hline $1040-1090$ & $\begin{array}{l}\text { C-O stretching of alcoholic compounds, } \\
\text { polysaccharides. }\end{array}$ \\
\hline $1137-1280$ & C-O stretching of esters, ethers and phenols. \\
\hline $1332-1390$ & Salts of carboxylic acids \\
\hline $1390-1400$ & $\begin{array}{l}\text { OH deformations and } \mathrm{C}-\mathrm{O} \text { stretching of phenolic } \\
\text { OH, C-H deformation of } \mathrm{CH}_{3} \text { groups. }\end{array}$ \\
\hline $1420-1470$ & Aliphatic C-H deformation. \\
\hline 1515 & C=C stretching in benzene and/or pyridine. \\
\hline $1585-1640$ & $\begin{array}{l}\text { C=O stretching of double bonds in cyclic and } \\
\text { acyclic compounds. }\end{array}$ \\
\hline $1640-1725$ & C= O stretching of carboxylic acids. \\
\hline $1850-2500$ & Carboxylate ions. \\
\hline $2850-2950$ & Aliphatic C-H, C- $\mathrm{H}_{2}, \mathrm{C}-\mathrm{H}_{3}$ stretching. \\
\hline $3030-3077$ & Aromatic C-H stretching. \\
\hline $3300-3670$ & Hydrogen-bonded $\mathrm{OH}$ groups. \\
\hline
\end{tabular}

The ability of peat to accumulate major and trace metals depends on the ability of metal ions to bind with the common functionalities in the structure of peat, and, as a consequence of this, the ability of metals can be arranged in the sequence: $\mathrm{Hg}>\mathrm{Cu}>\mathrm{Pb}>\mathrm{Ni}>\mathrm{Zn}>\mathrm{Co}>\mathrm{Cd}>\mathrm{Mn}$. The dominant sources of major and trace elements in peat mass can be attributed to atmospheric precipitations, to metals present in the peat- forming plants as well as to supply from groundwater and surface runoff. In many contemporary studies it is concluded that main sources of major and trace elements in peat are anthropogenic pollution; however, in most cases only upper peat layers are analysed.

Interrelations of major and trace elements are similar and subject to similar regularities, but their concentrations are purely individual in accordance with the specific conditions of mire.

In a large dose all metallic elements, but in particular heavy metals, are serious contaminants and cause not only the degradation of vegetation, but also human health problems. Heavy metals are not biodegradable and they tend to accumulate in living organisms and cause a variety of disorders and diseases such as peripheral neuropathy, multiple sclerosis, cancer and others [5]. The increase of the content of heavy metals in the environment is a global problem and is a growing threat to humanity [6]. Heavy metals are naturally occurring substances, but they also form as by-products of industrial activity and the spread of them should be limited to a minimum. In general, humans and other organisms are exposed to heavy metals from food and water, therefore, one of the largest challenges is the potential for the bioaccumulation and biomagnification of heavy metals in the food chain [7]. Water plays an important role and life in biogeochemical cycles and in human development, but the increase of environmental and water pollution is a major concern nowadays, hence, there is an urgent need to find any possibility to treat the environment before heavy metals are discharged into food or water bodies. To promote the sustainable environment high on the agenda is to limit heavy metal contamination, particularly of that in wastewaters of metal plating facilities, tanneries and many other industries. The most popular methods in the decontamination of waste water are coagulation, membrane separation, oxidation and other physic-chemical methods [8], but these methods are expensive and have a lot of technical constraints and disposal problems. There is an urgent need to find a universal, simply operable and cost effective method in wastewater treatment not only in the decontamination of industrial waters, but also in the decontamination of any waste material which might end up in the water. One of the most promising solutions is the use of biosorbents. Several of the currently used biosorbents have proven their effectiveness, for instance, peat moss, seaweed, bacteria, wool and rice [9-11] and have high potential in environmental decontamination. The quality of peat and range of applications largely depends directly on major and trace element concentration in it. Physicochemical characteristics like high porosity, acid to alkaline $\mathrm{pH}$ reaction, modifiable specific surface area and high ion exchange capacity allow using the peat as a high-quality material for a variety of biosorbents [12]. In fact, the use of peat and peat products for the purpose of biosorption of heavy metals can be a technically feasible and an economically viable solution, because it is a low cost organic material which requires little processing and is abundant in nature [13-14]. Peat, most commonly - a peat fibre, due to its characteristics has been 
used as a filtration material for a variety of liquids, gases and odours [15]. Mostly, though the raised bog peat and products of its modification have been used; hence, the perspective of fen peat as a sorbent is not completely evaluated. The most common heavy metals with a significant influence on living organisms are arsenic (As), barium (Ba), cadmium $(\mathrm{Cd})$, chromium $(\mathrm{Cr})$, lead $(\mathrm{Pb})$, iron $(\mathrm{Fe})$, mercury $(\mathrm{Hg})$, selenium (Se) and silver $(\mathrm{Ag})$ [16]. The aim of this study was to analyse the sorption ability of fen peat and to assess the sorption capability of metallic elements $(\mathrm{Ca}, \mathrm{Mg}, \mathrm{K}, \mathrm{Na}, \mathrm{Cu}$ and $\mathrm{Pb}$ ) onto the fen peat.

\section{MATERIAL AND METHODS}

Peat samples with the vertical interval of $0.1 \mathrm{~m}$ were taken from fen peat profile from a minerotrophic fen in the territory of Latvia - Viki Mire. The botanical composition [17], decomposition degree [18-19], $\mathrm{pH}$ reaction and the concentration of metallic elements were determined before the sorption experiment has been performed. The sorption of $\mathrm{Ca}$, $\mathrm{Mg}, \mathrm{K}, \mathrm{Na}, \mathrm{Cu}$ and $\mathrm{Pb}$ onto the fen peat was performed in an aquatic environment using water-soluble reagents $\left(\mathrm{CaCl}_{2} \cdot 2 \mathrm{H}_{2} \mathrm{O} ; \mathrm{MgCl}_{2} \cdot 6 \mathrm{H}_{2} \mathrm{O} ; \mathrm{KCl} ; \mathrm{NaCl} ; \mathrm{CuSO}_{4} \cdot 5 \mathrm{H}_{2} \mathrm{O}\right.$ and $\left.\mathrm{Pb}\left(\mathrm{NO}_{3}\right)_{2}\right)$ which were diluted to $250 \mathrm{ml}$.

Equilibrium batch adsorption studies were carried out by mixing peat (100 $\mathrm{mg}$ of a ground peat sample (oven-dried at $105{ }^{\circ} \mathrm{C}$ for $\left.24 \mathrm{~h}\right)$ ) with aqueous metal solutions $(50 \mathrm{ml})$ of different concentrations in sealed containers at $25^{\circ} \mathrm{C}$ for $24 \mathrm{~h}$. Subsequently, samples were filtered and the amount of heavy metals in the filtrate was measured by atomic absorption spectrometer (PerkinElmer AAnalyst 200).

The values of the sorption capacity (equation 1) (SC) were calculated using the multiplication of the volume of the analytical solution $(V)$ and the difference between analytic concentrations before $\left(C_{n}\right)$ and after $\left(C_{a}\right)$ adsorption against the mass of the dried peat sample $(\mathrm{m})$. Sorption isotherms were created marking the $C_{b}(\mathrm{mg} / \mathrm{L})$ values on the $x$ axis and $S C(\mathrm{mg} / \mathrm{L})$ values on the y axis.

$$
S C=\frac{\left(C_{i}-C_{e}\right) \cdot V}{m}
$$

where "SC" - sorption capacity $(\mathrm{mg} / \mathrm{g})$, " $C_{i}$ " - analytic concentration before the adsorption $(\mathrm{mg} / \mathrm{L}), " C_{e}$ " - analytic concentration after the adsorption (mg/L), " $V$ " - volume of the analytic solution (L), " $m$ " - sample mass (g).

The appropriate model of the adsorption mechanism was created using the determination coefficients $\left(r^{2}\right)$ of the Langmuir and Freundlich adsorption models, which are the most often used adsorption models. The Langmuir adsorption model is based on the following assumptions: "adsorption is limited to monolayer coverage, all surface sites are alike and only can accommodate one adsorbed atom and the ability of a molecule to be adsorbed on a given site is independent of its neighbouring sites occupancy" [20], and can be written as the following (equation 2, 3):

$$
q_{e}=\frac{b \cdot C_{e} \cdot q_{\max }}{1+b \cdot C_{e}}
$$

where " $q_{e}$ " is the amount of metal sorbed at equilibrium $(\mathrm{mg} / \mathrm{g}), " q_{\max }$ " is the monolayer sorption capacity $(\mathrm{mg} / \mathrm{g})$, " $b$ " is Langmuir constant, " $C_{e}$ " is concentration of metal ions in solution at equilibrium.

One of the linear forms of Langmuir equation is:

$$
\frac{C_{e}}{q_{e}}=\frac{C_{e}}{q_{\max }}+\frac{1}{b \cdot q_{\max }}
$$

There must be a straight line with slope of $\left(1 / q_{\max }\right)$ and an intercept of $\left(1 / b \cdot q_{\max }\right)$ when a plot of $\left(C_{e} / q_{e}\right)$ versus $C_{e}$ is drawn.

Freundlich isotherm describes the equilibrium on heterogeneous surfaces and does not assume monolayer capacity [21].

The Freundlich equation is (equation 4, 5):

$$
q_{e}=K_{F} \cdot C_{e}^{\frac{1}{n}} \text { (nonlinear form) }
$$

$$
\log q_{e}=\log K_{F}+\frac{1}{n} \log C_{e}(\text { linear form })
$$

\section{RESULTS AND DISCUSSION}

In this study (Table III), the concentration of the initial solution was gradually increased and the metal adsorption ability of wood-grass and grass fen peat was examined. Our peat samples have a high content of metals naturally; therefore, its sorption capacity is lower than it is in a raised bog peat. The fen peat has a high natural concentration of $\mathrm{Ca}$, $\mathrm{Mg}$ and $\mathrm{Cu}$ (Table IV), while the concentration of potassium, sodium and lead in the peat mass with respect to raised bog peat are significantly lower.

TABLE III

Chemical Characteristics of ANALysed WoOd-Grass Fen PEAT SAMPLES

\begin{tabular}{|c|c|}
\hline Peat type & Wood-grass fen peat \\
\hline $\mathrm{pH}\left(\right.$ in $\left.\mathrm{H}_{2} \mathrm{O}\right)$ & 5.80 \\
\hline Organic matter, $\%$ & 91.8 \\
\hline Decomposition degree, $\%$ & 34 \\
\hline $\mathrm{C}, \%$ & 44.93 \\
\hline $\mathrm{H}, \%$ & 5.07 \\
\hline $\mathrm{N}, \%$ & 2.89 \\
\hline $\mathrm{S}, \%$ & $<0.5$ \\
\hline Specific surface area $\mathrm{BET}, \mathrm{m}^{2} / \mathrm{g}$ & 3.98 \\
\hline
\end{tabular}


TABLE IV

Natural Concentrations of Metals in the Fen PeAt vs. Element ADSORPTION CAPACITY (MG/G)

\begin{tabular}{|l|c|c|c|c|c|c|}
\hline & $\mathbf{C a}$ & $\mathbf{M g}$ & $\mathbf{K}$ & $\mathbf{N a}$ & $\mathbf{C u}$ & $\mathbf{P b}$ \\
\hline Natural concentration & 10.1 & 1.2 & 0.1 & 0.1 & 0.002 & 0.003 \\
\hline Adsorption capacity & 3 & 6 & 15 & 15 & 25 & 125 \\
\hline
\end{tabular}

The sorption capacity of elements onto the peat is influenced by peat properties and depends on the oxygencontaining functional groups and it is growing along with an increasing degree of decomposition. In addition, the raised bog peat seems to be largely unsaturated in respect to metal ions, while the situation is just the opposite with peat from the fens, where the metal sorption hypothetically takes place due to the competition with $\mathrm{Ca}$ and $\mathrm{Mg}$. Results show that adsorption abilities of metals are followed by geometric progression and it depends on the natural concentration of elements in peat - the higher is the natural concentration of metals in the peat, the lower is the adsorption capacity of this particular metal. In all our experiments peat samples with their natural $\mathrm{pH}$ reaction were used: the wood-grass peat with $\mathrm{pH} 5.8$ for Ca (Fig. 1); the grass peat with $\mathrm{pH} 6.0$ for $\mathrm{Mg}, \mathrm{K}$, $\mathrm{Na}$; the wood-grass peat with $\mathrm{pH} 5.7$ (Fig. 2) for $\mathrm{Cu}$ and the wood-grass fen peat with $\mathrm{pH} 5.8$ for lead.

$1 \mathrm{~g}$ of the dried fen peat in the natural conditions adsorbs $3 \mathrm{mg}$ of $\mathrm{Ca}$ and twice as many of $\mathrm{Mg}$; however the adsorption mechanism between wood-grass and grass peat is slightly different and the adsorption capacity can be reached faster in wood-grass peat.

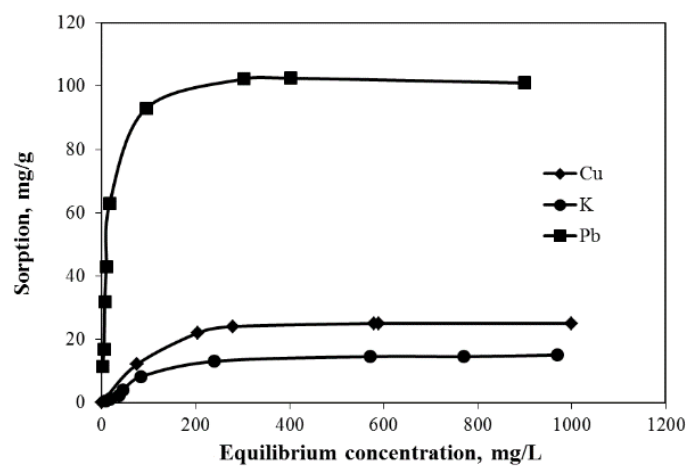

Fig. 1. Adsorption isotherms of $\mathrm{Cu}, \mathrm{K}$ and $\mathrm{Pb}$.

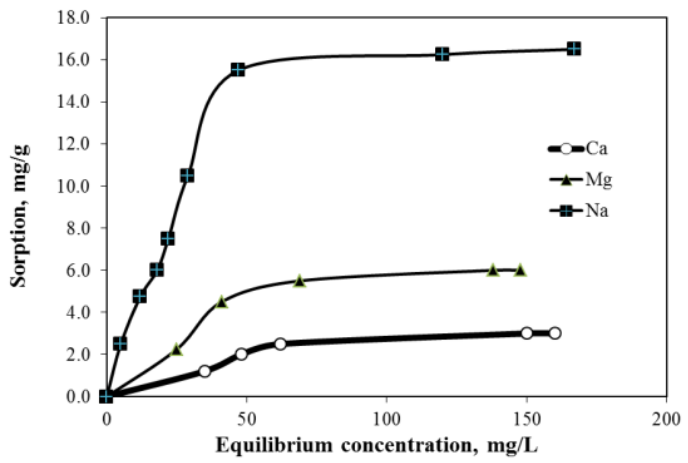

Fig. 2. Adsorption isotherms of $\mathrm{Ca}, \mathrm{Mg}$ and $\mathrm{Na}$.
The adsorption capacity of sodium and potassium is almost the same $(\sim 15 \mathrm{mg} / \mathrm{g})$ and so are the adsorption characteristics. The adsorption capacity of copper is even higher; it reaches $25 \mathrm{mg} / \mathrm{g}$ on the wood-grass peat, and obtained sorption capacity is compared with results reported in other studies (Table V). Lead in the wood-grass peat reaches its maximum capacity of $125 \mathrm{mg} / \mathrm{g}$.

Results show that the sorption capacity of $\mathrm{Ca}$ in our analysed peat is $13 \mathrm{mg} / \mathrm{g}$ from which only $3 \mathrm{mg} / \mathrm{g}$ can be adsorbed artificially. A different situation is with other elements - it is possible to adsorb magnesium three times more than the amount already in peat, yet this strongly depends on the content of $\mathrm{Ca}$, because both elements compete with one another. The most significant specialty of our analysed fen peat samples is lower lead content, which allows adsorbing almost $130 \mathrm{mg}$ of lead on a gram of peat mass. This sorption capacity is similar as adsorption capacity of peat used in other studies (e.g., $122 \mathrm{mg} / \mathrm{g}$ ) [32] and higher than sorption capacity of modified peat-resin particles (e.g., $47.39 \mathrm{mg} / \mathrm{g}$ ) [14]. Results show that, with an increase in the content of the analytic solution decreases the concentration of $\mathrm{Ca}$ and $\mathrm{Mg}$ in the peat sample and relatively high $\mathrm{pH}$ reaction allows metallic elements to migrate at a high rate, however, the naturally high metal content limits the sorption capacity of artificially added metals.

TABLE V

COMPARISON OF ADSORPTION CAPACITIES OF ANALYSED PEAT SAMPLES VERSUS PEAT IN OTHER COUNTRIES

\begin{tabular}{|c|c|c|c|c|}
\hline Type of peat & $\begin{array}{l}\mathrm{pH} \text { of } \\
\text { the } \\
\text { soluti- } \\
\text { on }\end{array}$ & $\begin{array}{l}\text { Tempe- } \\
\text { rature, } \\
{ }^{\circ} \mathrm{C}\end{array}$ & $\begin{array}{c}\text { Maximum } \\
\text { sorption } \\
\text { capacity, } \\
\text { mg/g }\end{array}$ & Reference \\
\hline $\begin{array}{l}\text { Wood-grass fen } \\
\text { peat }\end{array}$ & 5.8 & 25 & 25.0 & This study \\
\hline n.i. & 5.0 & n.i. & 12.6 & [22] \\
\hline $\begin{array}{c}\text { Canadian } \\
\text { Sphagnum peat }\end{array}$ & 4.0 & n.i. & 16.1 & [23] \\
\hline n.i. & 5.5 & 21 & 3.53 & [24] \\
\hline n.i. & 4.2 & $20 \pm 1$ & $\sim 28.0$ & [25] \\
\hline $\begin{array}{l}\text { Peat humus } \\
\text { (Alder Peat) }\end{array}$ & 4.0 & n.i. & 47.1 & [26] \\
\hline Modified peat & 4.5 & $25 \pm 0.5$ & $9.09 *$ & {$[14]$} \\
\hline $\begin{array}{l}\text { "Heilongjiang } \\
\text { peat" and } \\
\text { "Danish peat" }\end{array}$ & 6.0 & $\begin{array}{l}\text { Room } \\
\text { tempera- } \\
\text { ture }\end{array}$ & $\begin{array}{c}\sim 25.0 \text { and } \\
35.0\end{array}$ & {$[16]$} \\
\hline $\begin{array}{l}\text { "Westland Irish } \\
\text { moss peat" }\end{array}$ & 4.5 & 25 & 17.6 & [27] \\
\hline $\begin{array}{l}\text { Sphagnum and } \\
\text { Carex peat }\end{array}$ & 6.8 & $\begin{array}{l}\text { Room } \\
\text { tempera- } \\
\text { ture }\end{array}$ & $\begin{array}{l}25.1 \text { and } \\
25.4\end{array}$ & [28] \\
\hline n.i. & 4.0 & $22-25$ & $\sim 25.0$ & [29] \\
\hline $\begin{array}{l}\text { "Highly } \\
\text { mineralized" }\end{array}$ & n.i. & $\begin{array}{l}21.2- \\
21.4\end{array}$ & 8.4 & {$[30]$} \\
\hline "Irish peat" & 6.0 & 25 & 7.39 & {$[31]$} \\
\hline
\end{tabular}

* Determined by Langmuir equation

n.i. - not indicated 
The Langmuir and Freundlich equations were used to quantitatively describe the sorption isotherms. The parameters obtained in fitting the experimental data are summarized in Table VI. Highest $r^{2}$ values were obtained by fitting the Langmuir equation indicating that it was the best model to describe the adsorption of metals by fen peat. The maximum sorption capacities estimated by this model are close to the experimentally determined value.

TABLE VI

PARAMETERS OF LANGMUIR AND FREUNDLICH EQUATIONS

\begin{tabular}{|c|c|c|c|c|c|c|}
\hline & $\mathrm{Ca}$ & Mg & $\mathbf{K}$ & $\mathrm{Na}$ & $\mathrm{Cu}$ & $\mathbf{P b}$ \\
\hline \multicolumn{7}{|l|}{ Langmuir } \\
\hline$b, \mathrm{~L} / \mathrm{mg}$ & 0.0220 & 0.0224 & 0.0052 & 0.0295 & 0.0175 & 0.0058 \\
\hline$q_{\max }, \mathrm{mg} / \mathrm{g}$ & 3.70 & 8.01 & 18.43 & 20.47 & 26.89 & 137.44 \\
\hline$r^{2}$ & 0.96 & 0.99 & 0.95 & 0.98 & 0.99 & 0.98 \\
\hline \multicolumn{7}{|l|}{ Freundlich } \\
\hline$r^{2}$ & 0.78 & 0.91 & 0.90 & 0.90 & 0.76 & 0.90 \\
\hline
\end{tabular}

\section{CONCLUSION}

Fen peat has a huge variability as a biosorbent due to its variable botanical composition and complex properties, for instance, under equal conditions wood-sedge fen peat can have a higher lead adsorption capacity than wood fen peat. The adsorption of metallic elements occurs due to the replacement of $\mathrm{Ca}$ and $\mathrm{Mg}$. It was concluded that the adsorption of metals follows the Langmuir adsorption isotherms.

\section{ACKNOWLEDGEMENT}

This study has been carried out with the support of the European Social Fund project nr. 2014/0009/1DP/1.1.1.2.0/ 13/APIA/VIAA/04 "Starpdisciplināra jauno zinātnieku grupa Latvijas purvu un to resursu izpētei, ilgtspējīgai izmantošanai un aizsardzībai (PuReST)”.

\section{REFERENCES}

1. Gadd, G. M. Biosorption: critical review of scientific rationale, environmental importance and significance for pollution treatment. $J$. Chem. Technol. Biotechnol., 2009, No. 84, pp. 13-28.

http://dx.doi.org/10.1002/jctb.1999

2. Stuart, B. H. Infrared Spectroscopy: Fundamentals and Applications. John Wiley \& Sons, Ltd., 2004, vol. 8, 224 p.

3. Chapman, S. J., Campbell, C. D., Fraser, A. R., Puri, G. FTIR spectroscopy of peat in and bordering Scots pine woodland : relationship with chemical and biological properties. Soil Biology and Biochemistry, 2001, vol. 33, pp. 1193-1200. http://dx.doi.org/10.1016/S00380717(01)00023-2

4. Tolstoy, V. P., Chernyshova, I. V., Skryshevsky, V. A. Handbook of infrared spectroscopy. Wiley Online Library, 2003, vol. 126, No. 47, pp. 15633-15634. http://dx.doi.org/10.1002/047123432X

5. Brennan, B. M., Donlon, M., Bolton, E. Peat biofiltration as an odour control technology for sulphur-based odours. Water and Environment Journal, 1996, vol. 10, No. 3, pp. 190-198. http://dx.doi.org/10.1111/j.1747-6593.1996.tb00030.x

6. Martin, S., Griswold, W. Human health effects of heavy metals. Environmental Science and Technology Briefs for Citizens, 2009, vol. 15, pp. $1-6$.

7. Couillard, D. The use of peat in wastewater treatment. Water Research, 1994, vol. 28, No. 6, pp. 1261-1274. http://dx.doi.org/10.1016/0043$\underline{1354(94) 90291-7}$
8. Bulut, Y., Tez, Z. Removal of heavy metals from aqueous solution by sawdust adsorption. Journal of Environmental Sciences, 2007, vol. 19, pp. 160-166. http://dx.doi.org/10.1016/S1001-0742(07)60026-6

9. Dean, S. A., Tobin, J. M. Uptake of chromium cations and anions by milled peat. Resources, Conservation and Recycling, 1999, vol. 27, pp. 151-156. http://dx.doi.org/10.1016/S0921-3449(98)00095-0

10. Kratochvil, D., Pimentel, P., Volesky, B. Removal of trivalent and hexavalent chromium by seaweed biosorbent. Environmental Science Technology, 1998, vol. 32, pp. 2693-2698.

http://dx.doi.org/10.1021/es971073u

11. Stamboliadis, E., Emejulu, A., Pantelaki, O., Pentari, D., Petrakis, E. Removal of phenols from the water effluents of olive presses. Environmental and Climate Technologies, 2012, vol. 8, pp. 4-11. http://dx.doi.org/10.2478/v10145-012-0001-2

12. Joosten, H., Clarke, D. Wise Use of Mires and Peatlands. Devon: International Mire Conservation Group and International Peat Society, 2002. 304 p.

13. Dzugan, M., Zielinska, S., Heclik, J., Pieniqzeh, M., Szostek, M. Evaluation of heavy metals environmental contamination based on their concentrations in tissues of wild pheasant (phasianus colchicus L.). Journal of microbiology, Biotechnology and Food Sciences, 2012, vol. 2, No. 1, pp. 238-245.

14. Sun, Q. Y., Lu, P., Yang, L. Z. The adsorption of lead and copper from aqueous solution on modified peat-resin particles. Environmental Geochemistry and Health, 2003, vol. 37, pp. 1535-1544. http://dx.doi.org/10.1023/B:EGAH.0000039595.12014.6b

15. Zhuang, P., Zou, H., Shu, W. Biotransfer of heavy metals along a soilplant-insect-chicken food chain: Field study. Journal of Environmental Science, 2009, vol. 21, No. 6, pp. 849-853.

http://dx.doi.org/10.1016/S1001-0742(08)62351-7

16. Qin, F., Wen, B., Shan, X. Q., Xie, Y. N., Liu, T., Zhang, S. Z., Khan, S. U. Mechanisms of competitive adsorption of $\mathrm{Pb}, \mathrm{Cu}$ and $\mathrm{Cd}$ on peat. Environmental Pollution, 2006, vol. 144, pp. 669-680. http://dx.doi.org/10.1016/j.envpol.2005.12.036

17. Katz, N. J., Katz, S. V., Skobeyeva, E. I. Atlas rastitelnyh ostatkov v torfje (Atlas of Plant Remains in Peats). Moscow: Nedra, 1977. (In Russian).

18. Mauquoy, D., Hughes, P. D. M., van Geel, B. A protocol for plant macrofossil analysis of peat deposits. Mires and Peat 7, 2010, No. 11, pp. 1-5.

19. Malterer, T., Verry, E., Erjavec, J. Fiber content and degree of decomposition in peats: review of national methods. Soil Science Society of America Journal, 1992, vol. 56, No. 4, pp. 1200-1211. http://dx.doi.org/10.2136/sssaj1992.03615995005600040033x

20. Febrianto J, Kosasiha A. N, Sunarsob J, Jua Y, N. Indraswati, Ismadji S. Equilibrium and kinetic studies in adsorption of heavy metals using biosorbent: A summary of recent studies. J Hazard Mater, 2004, vol. 162, pp. 616-645. http://dx.doi.org/10.1016/j.jhazmat.2008.06.042

21. Mohan, D., Pittman, J. C. U. Activated carbons and low cost adsorbents for remediation of tri- and hexavalent chromium from water. J Hazard Mater, 2006, No. 137, pp. 762-811. http://dx.doi.org/10.1016/j.jhazmat.2006.06.060

22. Ho, Y. S., \& Mckay, G.. Y. S. Ho, G. McKay. Sorption of copper (II) from aqueous solution by peat. Water, Air and Soil Pollution, 2004, vol. 158, pp. 77-97. http://dx.doi.org/10.1023/B:WATE.0000044830.63767.a3

23. Gardea-Torresdey, J. L., Tang, L., Salvador, J. M. Copper adsorption by esterified and unesterified fractions of Sphagnum peat moss and its different humic substances. Journal of Hazardous Materials, 1996, vol. 48, pp. 191-206. http://dx.doi.org/10.1016/0304-3894(95)00156-5

24. Gündaĝan, R., Acemioĝlu, B. and Alma, M. H. Copper (II) adsorption from aqueous solution by herbaceous peat. Journal of Colloid and Interface Science, 2004, vol. 269, No. 2, pp. 303-309. http://dx.doi.org/10.1016/S0021-9797(03)00762-8

25. Cochrane, E. L., Lu, S., Gibb, S. W., Villaescusa, I. A comparison of low-cost biosorbents and commercial sorbents for the removal of copper from aqueous media. Journal of Hazardous Materials, 2006, vol. 137, No. 1, pp. 198-206. http://dx.doi.org/10.1016/j.jhazmat.2006.01.054

26. Twardowska, P. I., Kyziol, J. Binding and Chemical Fractionation of Heavy Metals in Typical Peat Matter. Fresenius J Anal Chem, 1996, vol. 354, pp. 580-586. http://dx.doi.org/10.1007/s0021663540580

27. Sen Gupta, B., Curran, M., Hasan, S., Ghosh, T. K. Adsorption characteristics of $\mathrm{Cu}$ and $\mathrm{Ni}$ on Irish peat moss. Journal of Environmental Management, 2009, vol. 90, No. 2, pp. 954-960. http://dx.doi.org/10.1016/j.jenvman.2008.02.012 
28. Ringqvist, L., Oborn, I. Copper and zinc adsorption onto poorly humified Sphagnum and Carex peat. Water research, 2002, vol. 36, No. 9, pp. 2233-2242. http://dx.doi.org/10.1016/S0043-1354(01)00431-6

29. Ma, W., Tobin, J. M. Determination and modelling of effects of $\mathrm{pH}$ on peat biosorption of chromium, copper and cadmium. Biochemical Engineering Journal, 2004, vol. 18, No. 1, pp. 33-40. http://dx.doi.org/10.1016/S1369-703X(03)00118-9

30. Koivula, M. P, Kauko K., Rönkkömäki, H., Mäkelä, M. Sorption of $\mathrm{Pb}$ (II), $\mathrm{Cr}$ (III), $\mathrm{Cu}$ (II), As (III) to Peat, and Utilization of the Sorption Properties in Industrial Waste Landfill Hydraulic Barrier Layers. Journal of Hazardous Materials, 2009, No. 164, pp. 345-52. http://dx.doi.org/10.1016/j.jhazmat.2008.08.008

31. Zhi-rong, L. I. U., Li-Min, Z., Peng, W. E. I., Kai, Z., Chuan-Xi, W. E. N., Hui-Hua, L. A. N. Competitive adsorption of heavy metal ions on peat Journal of China University of Mining and Technology, 2008, No. 18 , pp. 255-260. http://dx.doi.org/10.1016/S1006-1266(08)60054-1

32. Ho, Y. S. and McKay, G. Batch lead (II) removal from aqueous solution by peat: Equilibrium and kinetics. Process Safety and Environmental Protection, 1999, vol. 77, No. B3, pp. 165-173. http://dx.doi.org/10.1205/095758299529983

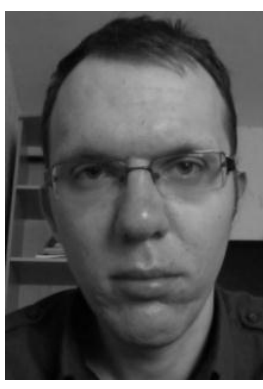

Janis Krumins, M. Sc. geol. PhD student in Environmental Science at the University of Latvia, Faculty of Geography and Earth Sciences. Bachelor degree in geology earned at the University of Latvia in 2009; Master degree in geology earned at the University of Latvia in 2011. The major interests are related to applied geology, quaternary geology, environmental science, nature conservation.

Address: University of Latvia, Raina Blvd. 19, LV1586, Riga, Latvia.

E-mail: krumins.janis@hotmail.com

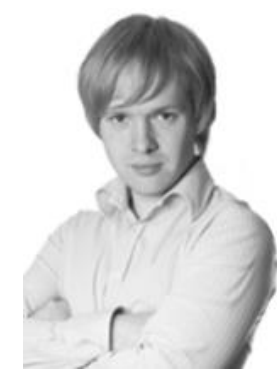

Artis Robalds, Mg. sc. env., PhD. student at the University of Latvia, Faculty of Geography and Earth Sciences, Department of Environmental Sciences. Research interests are related to constructed wetlands, peat and other biosorbents in the treatment of polluted waters (heavy metals, phosphates).

Address: University of Latvia, Raina Blvd. 19, LV-1586, Riga, Latvia.

E-mail: artis.robalds@lu.lv; artis.robalds@inbox.lv 